US nuclear power

\section{Close friends are enemies}

Washington

THE US Nuclear Regulatory Commission (NRC) has failed in its primary responsibility as protector of public safety and has instead behaved like a promoter of nuclear power, according to a document ${ }^{*}$ put out by the Union of Concerned Scientists (UCS). It accuses NRC of deferring important safety issues by labelling them as "generic", of hampering public access to information and of failing to enforce even its own regulations.

UCS gives numerous examples where inadequate enforcement by NRC at an early stage of construction of a plant meant that changes had to be made later, often at enormous expense. The Zimmer Plant in Ohio, finally cancelled in 1984 after a painful series of investigations and accusations of improper conduct, is cited as an example of a plant killed by ineffective regulation. The Diablo Canyon plant, which is now operating, would have been in operation much sooner had there not been a breakdown in the quality assurance programme which caused some seismic protection modifications to be carried out with reversed blueprints. The list goes on.

The UCS report also reveals disturbing instances of apparent attempts within the commission to conceal reviews whose results could cast an unfavourable light on the commission or its senior staff. A federal grand jury is at present investigating allegations of criminal misconduct by some NRC officials. UCS also describes instances of NRC's unwillingness to cooperate in congressional investigations which have led to complaints by congressmen.

UCS says the delay in considering generic safety issues is leading directly to danger to public health. Several generic safety issues implicated in the Three-Mile Island accident, for example, have still not been resolved. NRC schedules are described as being "among the most flexible" in any branch of government. In other cases, safety regulations have been revised after it became clear that many plants would have to shut down temporarily in order to comply with regulations. UCS also notes that when NRC says a "generic" safety issue has been resolved, it means only that agreement has been reached on how the problem might be tackled.

UCS has a long history of involvement with nuclear safety issues and claims to have been instrumental in bringing to light safety issues that have later been accepted and enforced by NRC. The union's general position is that it believes nuclear power can be safely regulated but that NRC has so far failed to do this. Despite some evidence of a tightening-up of procedures at NRC after the 1979 Three-Mile Island accident, the

\footnotetext{
* Safety Second: A critical evaluation of the NRC's first decade.
} Union of Concerned Scientists. change was short-lived, according to UCS. The problem is not the competence of the NRC staff, but the attitudes of senior management, who set the tone for NRC conduct: "Like bureaucrats everywhere, the staff do what they think they are expected to do", in the words of John Pollard, a former NRC engineer who defected to UCS in 1976. The senior management, many of whom have been with the commission since it was formed as a spin-off from the Atomic Energy Commission in 1975, are accused of having too close a relationship with the industry.

The chairman of NRC, Nunzio Palladino, has said that while NRC welcomes constructive criticism, UCS "goes overboard". He pointed out that although UCS accuses it of putting the interests of the power industry first, the industry accuses it of being adversarial, so "we must be doing something right".

UCS proposes that NRC should establish deadlines for resolution of safety issues, and that a new Inspector General should be answerable to the President and Congress on NRC affairs. An independent Nuclear Safety Board is also proposed.

Despite optimistic assessments of the future potential of nuclear power in the United States from industry groups, the fact remains that no new plants have been ordered since 1978 and that all plants ordered since 1974 on which construction had started have been cancelled. Both industry and NRC recognize that the licensing process has hampered construction and are pressing for reform; in particular, NRC recently proposed that it should be able to issue a combined construction permit and operating licence for standardized plant designs rather than hold separate inquiries, as at present. (The UCS report notes that holding an operating licence hearing when a billion-dollar plant has already been built almost guarantees the outcome will be approval.) The UCS critique agrees that a single decision on a proposed plant would be preferable to the present system, but insists that the design and the site location should be finalized before the inquiry is held. According to proposed legislation recently sent to Congress by NRC, however, the commission would be able to approve "essentially complete" designs and to grant site permits even if no specific application to build at a particular location had been received. But that, according to UCS, is a recipe for a continuation of the delays and expensive alterations that have plagued the industry so far.

Tim Beardsley

\title{
Straw in the wind
}

THE first resignation from the Natural Environment Research Council in the wake of publication of its corporate plan (Nature 14 February, p.517) has come about. Professor J.F. Dewey, a geologist from the University of Durham, last week announced that he had resigned and further embarrassed the council by saying why. The council had no comment to make earlier this week.

Dewey's resignation statement says that the publication of the corporate plan "brings to a head"' long-standing problems about the council's role as the sole source of support for the earth sciences in Britain. $\mathrm{He}$ says there is a general consensus that economically important earth sciences are being neglected financially, and that the trouble is not so much the total budget allocation to the research council as the diversity of the council's responsibilities.

The statement goes on to complain of the plight of the British Geological Survey, which is said to be "enmeshed in an incongruous maze" of long-term strategic research "which is its proper function" and short-term contract research, where it has to compete with private organizations for contracts. Dewey complains that as a result, exploration for oil and gas in the North Sea has often to be carried out with the help of geological maps first made in Victorian times.

Dewey also complains about the pro- posal in the council's corporate plan that the direction of research should in future be controlled by three senior members of the council based at its headquarters. Dewey says this is "a potentially very serious concept" that will generate more "showcase" research to the neglect of basic science.

In an unkind cut, Dewey says there is a case for transferring support for basic research in the earth sciences to the Science and Engineering Research Council. "To use the term environmental science" to describe their work suggests an inappropriate lack of rigour. "The essence of my view is that the council should no longer be responsible for the earth sciences."

Dewey's complaints closely echo others now common in the British earth sciences community, where the plight of the British Geological Survey is regarded as not much more serious than the place of geophysical techniques within classical geology. The postponement of British participation in the revamped International Deep-Sea Drilling programme at least until October is taken as a gloomy portent.

What can be done about the complaints remains to be seen. The Advisory Board for the Research Councils is too busy preparing financial applications for the year beginning in April 1986 to want to interfere at this stage, but ministers could change events by asking the right questions. 